Beach, Fla., and Amy Beckman of Sterling; his father, William, of McLean; a brother, Richard, of Philadelphia; and seven grandchildren.

[Reprinted from Washington Post, February 21, 1994]

\section{Mario Einaudi}

Mario Einaudi, Goldwin Smith Emeritus Professor at Cornell, died in Piedmont, Italy, in the house in which he was born almost 90 years ago.

The eldest son of Luigi Einaudi, economist and Italy's first president (1948-55), Einaudi's wisdom, dignity and love of freedom inspired generations of students at Cornell, and at the Foundation he later founded in his father's memory in Turin, Italy.

Einaudi received his degree at the University of Turin, where he studied alongside his lifelong friend Norberto Bobbio, Italy's premier political philosopher. He first came to the U.S. in 1927 as a Rockefeller Foundation fellow, returning in 1933 as a political exile after refusing to swear allegiance to Mussolini and fascism. Raising three sons in America with his wife, Manon Michels Einaudi (1904-90), he taught political science at Harvard, Fordham, and Cornell, serving twice as Department chair at the latter institution. In 1965, he was founding director of Cornell's Center for International Studies, which has borne his name since his departure from Ithaca in 1991.

At Cornell, Einaudi he stood out against the growing specialization in American academia, by teaching and writing in both political theory and comparative politics and creating the University's reputation in International affairs. As Milton Esman, his successor at the Center for International Studies, observes, "He introduced programs that he hoped would reach across areas and disciplines and would focus the attention of Cornell's students and faculty on the emerging problems of an interdependent world."

The 1960 s were a particular challenge for Einaudi and for Cornell. But Einaudi-though no radical- resisted the knee-jerk conservatism that led some of his colleagues to an outraged reaction to the 1969 occupation of the Cornell student union. His lifelong preoccupation was with freedom: from his dissertation on the eighteenth century French philosophers to his condemnation of postwar European communism, to his magisterial book on F.D.R., Einaudi stood for civility in public culture, a culture he sought to advance in his teaching, his writing and his statesmanship.

The depth of Einaudi's philosophical learning was revealed in his The Physiocratic Doctrine of Judicial Control (1937) and The Early Rousseau (1967), while he was making notable contributions to comparative politics in his works on Communism, Christian Democracy and Nationalization in Western Europe. In 1990, his contributions to political science were honored by his Cornell colleagues in Comparative Theory and Political Experience: Mario Einaudi and the Liberal Experience (Cornell University Press, edited by Peter J. Katzenstein, Theodore J. Lowi, and Sidney Tarrow).

Einaudi never stopped working to explain Europe to America and America to Europe. His most wellknown achievement in this regard was his The Roosevelt Revolution (1959), written to make the New Deal part of the remembered experience of the western world. "This was a bold and important message for the 1950s," wrote Einaudi's former colleague, Theodore Lowi, in his 1990 appreciation of Einaudi's work. Einaudi wrote the book out of fear that, as Europeans fell out of love with the Soviet model, they would drift toward fascism, and not toward the liberalism of the New Deal. Italy's move toward the extreme right in the elections of the last weeks of his life left him distressed and fearing for the country's future.

As he approached emeritus status, Einaudi began what amounted to a second career, founding and presiding over the Italian foundation that bears his father's name and was based on the elder Einaudi's remarkable library. For most of his last 30 years, he divided his time between Ithaca and the Foundation. His goal was to allow young scholars to carry on their research protected from the turbulence of the Italian university system. The Fondazione Luigi Einaudi today houses one of the world's most important economic history collections and provides postgraduate fellowships for students from around the world.

But at the same time, his commitment to Cornell and to its students and faculty never flagged. He was instrumental in the founding and expansion of the University's Western Societies Program and helped to establish a rotating chair for distinguished European intellectuals, the Luigi Einaudi Chair in European and International Studies.

Survivors include his sons Luigi of Bethesda, Maryland; Robert of Rome, Italy; Marc of Stanford, California; his 3 daughters-in-law, 9 grandchildren, and 2 brothers, Roberto and Giulio. At Cornell he leaves a Department bereft of a distinguished teacher, inspiring colleague, and dear friend. In lieu of flowers, the family believes that Professor Einaudi would wish contributions to be made to the Manon Michels Einaudi Travel Grants at the Institute for European Studies at Cornell.

Sidney Tarrow

Comell University

\section{William E. Lyons}

William E. (Bill) Lyons died of lung cancer on May 20,1994. He was born in 1935 in Martinsville, Virginia. He received a B.A. from Millersville State College in Pennsylvania in 1957, an M.A. from Temple in 1962 and a Ph.D. in political science from Penn State in 1965. He taught high school social studies in the late 1950s and was on the faculty at McMaster University in Hamilton, Ontario, Canada, for three years before coming to the University of Kentucky in 1967. He is survived by his wife Lynne, by two daughters, Kimberly Young and Dana Distler, and by two grandchildren.

Bill was the James Madison of 